\title{
Estradiol-Induced Estrogen Receptor- $\alpha$ Trafficking
}

\author{
Galyna Bondar, ${ }^{1}$ John Kuo, ${ }^{1,2}$ Naheed Hamid, ${ }^{1}$ and Paul Micevych ${ }^{1}$ \\ ${ }^{1}$ Department of Neurobiology, Laboratory of Neuroendocrinology and Brian Research Institute, and ${ }^{2}$ Department of Obstetrics and Gynecology, David \\ Geffen School of Medicine at the University of California, Los Angeles, California 90095
}

Estradiol has rapid actions in the CNS that are mediated by membrane estrogen receptors (ERs) and activate cell signaling pathways through interaction with metabotropic glutamate receptors (mGluRs). Membrane-initiated estradiol signaling increases the free cytoplasmic calcium concentration $\left(\left[\mathrm{Ca}^{2+}\right]_{i}\right)$ that stimulates the synthesis of neuroprogesterone in astrocytes. We used surface biotinylation to demonstrate that $\mathrm{ER} \alpha$ has an extracellular portion. In addition to the full-length $\mathrm{ER} \alpha$ [apparent molecular weight (MW), $66 \mathrm{kDa}$ ], surface biotinylation labeled an $\mathrm{ER} \alpha$-immunoreactive protein ( $\mathrm{MW}, \sim 52 \mathrm{kDa}$ ) identified by both $\mathrm{COOH}$ - and $\mathrm{NH}_{2}$-directed antibodies. Estradiol treatment regulated membrane levels of both proteins in parallel: within 5 min, estradiol significantly increased membrane levels of the 66 and $52 \mathrm{kDa} \mathrm{ER} \alpha$. Internalization, a measure of membrane receptor activation, was also increased by estradiol with a similar time course. Continuous treatment with estradiol for $24-48 \mathrm{~h}$ reduced ER $\alpha$ levels, suggesting receptor downregulation. Estradiol also increased mGluRla trafficking and internalization, consistent with the proposed ER $\alpha$-mGluRla interaction. Blocking ER with ICI 182,780 or mGluR1a with LY 367385 prevented ER $\alpha$ trafficking to and from the membrane. Estradiol-induced [Ca $\left.{ }^{2+}\right]_{\mathrm{i}}$ flux was also significantly increased at the time of peak ER $\alpha$ activation/internalization. These results demonstrate that ER $\alpha$ is present in the membrane and has an extracellular portion. Furthermore, membrane levels and internalization of ER $\alpha$ are regulated by estradiol and mGluRla ligands. The pattern of trafficking into and out of the membrane suggests that the changing concentration of estradiol during the estrous cycle regulates $\mathrm{ER} \alpha$ to augment and then terminate membrane-initiated signaling.

\section{Introduction}

Estradiol mediates numerous actions in the nervous system ranging from regulation of reproduction to learning and memory, and neuroprotection. The effects of estradiol on the brain involve both classical nuclear- and membrane-initiated actions. Nuclearinitiated actions are mediated through intracellular estrogen receptor- $\alpha(\mathrm{ER} \alpha)$ and $\mathrm{ER} \beta$ that behave as ligand-activated transcription factors. Evidence suggests that the same molecules activate $\mathrm{ER} \alpha$ - and $\mathrm{ER} \beta$-mediated nuclear-and membrane-initiated signaling. Both receptors have been demonstrated with a variety of methods, including immunoreactivity, Western blotting, and pharmacology, to mediate membrane-initiated steroid signaling (MISS) in neurons and glia (Lagrange et al., 1995, 1996; Ivanova et al., 2001; Kelly and Levin, 2001; Wade et al., 2001; Chaban et al., 2004; Acconcia et al., 2005; Pawlak et al., 2005; Mhyre and Dorsa, 2006; Pedram et al., 2006; Hirahara et al., 2009; for review, see Micevych and Dominguez, 2009; Sakuma et al., 2009). MISS activates G-protein-dependent cell signaling cascades (Hammes and Levin, 2007), including activation of the mitogen-activated protein kinase pathway, activation of protein kinase $\mathrm{C}(\mathrm{PKC})$, increase in $\left[\mathrm{Ca}^{2+}\right]_{\mathrm{i}}$, and phosphorylation of cAMP-responsive element binding protein (CREB) (Dewing et al., 2007, 2008; for review, see Kelly and Ronnekleiv, 2008). MISS acting through

Received May 2, 2009; revised Sept. 22, 2009; accepted 0ct. 19, 2009.

This work was supported by National Institutes of Health Grants HD042635 and HD001281. We thank Dr. Dennis Lubahn at the University of Missouri for his kind gift of $E R \alpha$ knock-out mice.

Correspondence should be addressed to Dr. Paul Micevych, Department of Neurobiology, David Geffen School of Medicine at the University of California, Los Angeles, CA 90095-1763. E-mail: pmicevych@mednet. ucla.edu. DOI:10.1523/JNEUROSCI.2107-09.2009

Copyright $\odot 2009$ Society for Neuroscience $\quad$ 0270-6474/09/2915323-08\$15.00/0
pCREB increases the expression of reproductive neuropeptides (Watters and Dorsa, 1998).

The estradiol-activated MISS depends on the transactivation of metabotropic glutamate receptors (mGluRs) by membrane ER $\alpha$ (Boulware et al., 2005, 2007; Dewing et al., 2007, 2008; Micevych and Mermelstein, 2008), which also activates PKC, increases $\left[\mathrm{Ca}^{2+}\right]_{\mathrm{i}}$, and phosphorylates CREB (Boulware et al., 2005, 2007; Dewing et al., 2007, 2008; Zhao and Brinton, 2007; for review, see Micevych and Mermelstein, 2008). In astrocytes, coimmunoprecipitation studies demonstrate a direct interaction of $66 \mathrm{kDa} \operatorname{ER} \alpha$ with the mGluRla, and blockade of the mGluRla prevents the estradiol-induced $\left[\mathrm{Ca}^{2+}\right]_{\mathrm{i}}$ flux needed to stimulate the synthesis of neuroprogesterone (Micevych et al., 2007; Kuo et al., 2009). In addition to the ER $\alpha-$ mGluR1a interaction, when $\mathrm{ER} \alpha$ interacts with the $\mathrm{mGluR} 2 / 3$, it inhibits adenylyl cyclase-dependent calcium influx through L-type voltage-gated calcium channels. These variable interactions with mGluRs account for both the facilitatory and inhibitory effects of estradiol (Chaban et al., 2003; Li et al., 2008; Mermelstein and Micevych, 2008).

We examined the regulation of membrane ER $\alpha$ by estradiol using surface biotinylation in astrocytes (Busch et al., 1989; Brandli et al., 1990; Lin et al., 2000; Sabarth et al., 2002; Gorosito et al., 2008). Membrane proteins including ER $\alpha$ were biotinylated by a membrane-impermeable reagent that prevented labeling of intracellular proteins. Exposure to estradiol for $5 \mathrm{~min}$ transiently increased 66 and $52 \mathrm{KDa} \mathrm{ER} \alpha$ membrane levels and their internalization. This receptor trafficking was dependent on mGluRla. The estradiol-induced $\left[\mathrm{Ca}^{2+}\right]_{\mathrm{i}}$ flux coincided with the maximal internalization/activation of $\mathrm{ER} \alpha$ levels. Continuous 
exposure to estradiol eventually reduced both membrane ER $\alpha$ and its internalization to basal levels, suggesting downregulation of the receptor. Together, these experiments demonstrate an autoregulation of estradiol signaling in astrocytes that may represent a common signaling mechanism in the CNS.

\section{Materials and Methods}

Animals and cultures. Primary hypothalamic astrocyte cultures were prepared from 40-d-old Long-Evans female rats (Charles River) and from 60-d-old female mice [C57BL/6 wild-type (WT) and ER $\alpha$ knock-out $(\mathrm{ER} \alpha \mathrm{KO})$; a gift from Dr. D. Lubahn, University of Missouri, Columbia, MO] as described previously (Micevych et al., 2007). All experimental procedures were approved by the Chancellor's Animal Research Committee at the University of California at Los Angeles. Briefly, a hypothalamic block was isolated with the following boundaries: the rostral extent of the optic chiasm, rostral extent of the mammillary bodies, lateral edges of the tuber cinereum, and top of the third ventricle. Hypothalamic tissue was dissociated with $2.5 \%$ trypsin (Invitrogen) and a fire-polished glass Pasteur pipette. Cultures were maintained at $37^{\circ} \mathrm{C}$ with $5 \% \mathrm{CO}_{2}$ and grown in DMEM/F-12 medium (Mediatech) with $10 \%$ fetal bovine serum (FBS; Hyclone) and 1\% penicillin-streptomycin (PS; Mediatech) for $14 \mathrm{~d}$.

Biotinylation. Astrocytes were pretreated for $12 \mathrm{~h}$ with $5 \%$ charcoalstripped FBS DMEM/F-12 medium and incubated with vehicle or in the presence $1 \mathrm{~nm} 17 \beta$-estradiol (Sigma-Aldrich) for 0, 5, and $30 \mathrm{~min}$ and 1 , 2,24 , and $48 \mathrm{~h}$ at $37^{\circ} \mathrm{C}$. Cells then were washed three times with ice-cold PBS buffer and incubated with freshly prepared $0.5 \mathrm{mg} / \mathrm{ml}$ EZ-Link Sulfo-NHS-LC-Biotin (Pierce) in PBS at $4^{\circ} \mathrm{C}$ for $30 \mathrm{~min}$ with gentle agitation. Excess biotin reagent was quenched by rinsing the cells three times with ice-cold glycine buffer (50 mM glycine in PBS). Then the cells were scraped into $10 \mathrm{ml}$ of PBS solution, transferred into a $50 \mathrm{ml}$ conical tube, and centrifuged at $500 \times g$ for $3 \mathrm{~min}$. The pellet was washed twice with ice-cold PBS and resuspended in $200 \mathrm{ml}$ of RIPA Lysis Buffer (Santa Cruz Biotechnology) containing the following proteases inhibitors: $1 \mathrm{~mm}$ phenylmethylsulfonyl fluoride, $1 \mathrm{~mm}$ EDTA, $1 \mu \mathrm{g} / \mathrm{ml}$ pepstatin, $1 \mu \mathrm{g} / \mathrm{ml}$ leupeptin, $1 \mu \mathrm{g} / \mathrm{ml}$ aprotinin, and $1 \mathrm{~mm}$ sodium orthovanadate (all inhibitors were from Santa Cruz Biotechnology). The cells were homogenized by passing them through a 25 gauge needle. The cell extract was centrifuged at $10,000 \times g$ for $2 \mathrm{~min}$ at $4^{\circ} \mathrm{C}$, and the protein concentration of the supernatant was determined using the Bradford Assay (Bio-Rad). Two hundred microliters of each sample with $1500 \mu \mathrm{g} / \mathrm{ml}$ protein concentration (rat astrocytes) or $950 \mu \mathrm{g} / \mathrm{ml}$ protein concentration (mouse astrocytes) was incubated with $200 \mu \mathrm{l}$ of Immobilized NeutrAvidin Gel (Pierce) for $2 \mathrm{~h}$ at room temperature and spun for $1 \mathrm{~min}$ at $1000 \times \mathrm{g}$. The beads were washed four times with $1 \mathrm{ml}$ of radioimmunoprecipitation assay (RIPA) buffer (Santa Cruz Biotechnology) containing the same proteases inhibitors mentioned previously. The bound proteins were eluted with SDS-PAGE sample buffer supplemented with $50 \mathrm{~mm}$ dithiothreitol (DTT) for $1 \mathrm{~h}$ at $37^{\circ} \mathrm{C}$.

Internalization. Internalization of $\mathrm{ER} \alpha$ was analyzed using a reversible biotinylation technique and was modified from the methods described previously. Cells were preincubated for $12 \mathrm{~h}$ with charcoal-stripped medium and cooled to $4^{\circ} \mathrm{C}$ by washing three times with ice-cold PBS. Then cells were biotinylated with freshly prepared $0.5 \mathrm{mg} / \mathrm{ml}$ EZ-Link SulfoNHS-LC-Biotin in PBS for $30 \mathrm{~min}$ at $4^{\circ} \mathrm{C}$, and the free biotinylating reagent was quenched with glycine buffer. Cells were incubated with $1 \mathrm{~nm}$ $17 \beta$-estradiol for 0,5 , and $30 \mathrm{~min}$ and $1,2,24$, and $48 \mathrm{~h}$. At the end of each time point, the reagents were removed, and the cells were washed with prechilled medium. The remaining biotinylated proteins on the cell surface were stripped with glutathione buffer ( $50 \mathrm{~mm}$ glutathione, $75 \mathrm{~mm}$ $\mathrm{NaCl}, 75 \mathrm{~mm} \mathrm{NaOH}$ in $\mathrm{H}_{2} \mathrm{O}$ ). Cells were then washed twice for $15 \mathrm{~min}$ at $4^{\circ} \mathrm{C}$ with iodoacetamide buffer ( $50 \mathrm{~mm}$ iodoacetamide in PBS, $\mathrm{pH} 7.4$ ) to quench residual glutathione. The internalized proteins labeled with biotin were protected from stripping, and the subsequent analysis provided an assay for protein internalization. For isolation, the biotinylated proteins in the supernatant of the cell lysate were mixed with Immobilized NeutrAvidin Gel (Pierce). To define the total amount of biotinylated receptors, one flask was not stripped with glutathione buffer and directly processed for extraction, followed by isolation with NeutrAvidin Gel. After incubation for $2 \mathrm{~h}$ at room temperature, the beads were washed four times with RIPA buffer (Santa Cruz Biotechnology) and eluted with SDS-PAGE sample buffer supplemented with $50 \mathrm{~mm}$ DTT for $1 \mathrm{~h}$ at $37^{\circ} \mathrm{C}$. All the proteins were resolved by SDS-PAGE.

To study ER trafficking to the membrane, astrocytes were (1) treated with 1 nм $\beta$-estradiol 6-(O-carboxy-methyl) oxime BSA (E-6-BSA; Sigma-Aldrich) for 0,5 , and $30 \mathrm{~min}$ and 1,2, 24, and $48 \mathrm{~h}$ before biotinylation to test whether ER $\alpha$ trafficking required estradiol access to the cell interior; (2) incubated with the ER antagonist ICI 182,780 ( $1 \mu \mathrm{M}$; Tocris) for $1 \mathrm{~h}$ before and during the treatment with $1 \mathrm{~nm}$ estradiol to confirm that activation of $\mathrm{ER} \alpha$ is essential for estradiol signaling; and (3) incubated with the mGluR1a antagonist LY 367385 (50 $\mu \mathrm{M}$; Tocris) for $1 \mathrm{~h}$ before and during the treatment with estradiol to confirm the necessity of $\mathrm{ER} \alpha$-mGluRla interaction in $\mathrm{ER} \alpha$ trafficking. The plasma membrane and internalized concentrations of the respective proteins were determined.

Western blotting. Samples were separated on 10\% Tris-HCl Ready Gels (Bio-Rad), and the proteins were transferred to polyvinylidene difluoride membranes (GE Healthcare). For determination of the molecular weight of the proteins, samples were run with Biotinylated Protein Ladder (Cell Signaling). To detect the $\mathrm{COOH}$ terminal of $\mathrm{ER} \alpha$, a rabbit polyclonal ER $\alpha$ antibody (C1355; 1:1000; Millipore) and a rabbit polyclonal ER $\alpha$ antibody (MC-20; 1:1000; Santa Cruz Biotechnology) were used. To detect the $\mathrm{NH}_{2}$ terminal of $\mathrm{ER} \alpha$, a rabbit polyclonal $\mathrm{ER} \alpha$ antibody (ab3574; 1:1000; Abcam) and a rabbit polyclonal ER $\alpha$ antibody (H-184; 1:1000; Santa Cruz Biotechnology) were used. For GPR30, a rabbit polyclonal GPR30 antibody (1:250; Abcam) was used. To detect the cytoplasmic protein LIM domain kinase 1 (LIMK1), a rabbit polyclonal LIMK1 antibody (1:1000; Abcam) was used. For mGluRla, a rabbit polyclonal mGluR1a antibody (1:1000; Millipore) was used. $\beta$-Actin was used as a loading control and detected by a rabbit polyclonal $\beta$-actin anitbody (1:5000; Abcam). A secondary donkey anti-rabbit $\operatorname{IgG}(\mathrm{H}+\mathrm{L})$ antibody $(1$ : 5000; Jackson ImmunoResearch) and a goat anti-biotin, HRP-linked antibody (1:1000; Cell Signaling) were then used ( $1.5 \mathrm{~h}$ incubation). Bands were visualized using an enhanced chemiluminescence (ECL) kit and ECL hyperfilm (GE Healthcare). Routine exposures varied from 0.5 to $2 \mathrm{~min}$. For detection of the $66 \mathrm{kDa}$ ER $\alpha$ band, the exposure time was $2 \mathrm{~h}$.

Intracellular $\mathrm{Ca}^{2+}$ measurements. Primary astrocyte cultures were grown in DMEM/F-12 medium with 10\% FBS and 1\% PS. The astrocytes were washed with HBSS (Mediatech), dissociated with a $2.5 \%$ trypsin solution, and resuspended in $5 \mathrm{ml}$ of DMEM/F-12 medium with $10 \%$ FBS. These cells were centrifuged for $3 \mathrm{~min}$ at $80 \times \mathrm{g}$, plated onto polyD-lysine $(0.1 \mathrm{mg} / \mathrm{ml}$; Sigma-Aldrich)-coated $15 \mathrm{~mm}$ glass coverslips, and incubated for $48-72 \mathrm{~h}$ in vitro before $\mathrm{Ca}^{2+}$ imaging. Cultures were routinely checked for purity using immunocytochemistry for glial fibrillary acidic protein (Millipore) and Hoechst 3342 (Sigma-Aldrich) nuclear stain. Cultures were determined to be $>95 \%$ pure astrocytes as reported previously (Sinchak et al., 2003; Micevych et al., 2007; Kuo et al., 2009).

Before experimentation, astrocytes were either nonsteroid starved or steroid starved for 6 or $12 \mathrm{~h}$ by incubating in DMEM/F-12 medium with $5 \%$ charcoal-stripped FBS at $37^{\circ} \mathrm{C}$. Astrocytes were loaded with the calcium indicator Fluo-4 AM (4.5 $\mu \mathrm{M}$; Invitrogen), dissolved in dimethyl sulfoxide and methanol, and diluted in HBSS. The cells were then washed three times with HBSS to remove the excess Fluo-4 AM. For the calcium imaging after preexposure to estradiol, astrocytes were steroid starved for $12 \mathrm{~h}$, loaded with Fluo-4 AM, and exposed to $1 \mathrm{nM}$ cyclodextrinencapsulated $17 \beta$-estradiol (Sigma-Aldrich) for 0,5 , and 30 min and 1 or $2 \mathrm{~h}$ before stimulation with $10 \mathrm{~nm}$ cyclodextrin-encapsulated $17 \beta$ estradiol in HBSS.

The coverslips containing astrocytes were mounted into a $50 \mathrm{~mm}$ RC-61T-01 chamber insert (Warner Instruments) fixed into a $60 \times 15$ $\mathrm{mm}$ cell culture dish (Corning) and placed into a QE-2 quick exchange platform (Warner Instruments). Test solutions were delivered by gravity perfusion through PE160 tubing and MP series perfusion manifold (Warner Instruments) and removed by vacuum suction at the opposite end of the perfusion chamber. Fluo-4 AM imaging was performed using an Axioplan2-LSM 510 Meta confocal microscope (Zeiss) with an IRAchroplan $40 \times / 0.80$ water-immersion objective (Zeiss) with $488 \mathrm{~nm}$ 
laser excitation and emission monitored through a low-pass filter with a cutoff at $505 \mathrm{~nm}$.

Statistics. For the Western blotting of surface biotinylation/internalization experiments, the optical density of each immunoreactive band was determined. Levels of $\beta$-actin were compared to ensure uniformity in protein loading for each experiment. Immunoreactive $\mathrm{ER} \alpha$ was normalized to $\beta$-actin for each sample and multiplied by 100 to obtain the percentage of protein ratio. Results are presented as SEM of at least four trials. The ratios were then compared with the 0 min time point as described below. For the $\mathrm{Ca}^{2+}$ imaging experiments, data are presented as mean \pm SEM in relative fluorescent units (RFU). The change in relative $\mathrm{Ca}^{2+}$ fluorescence $\left(\Delta F \mathrm{Ca}^{2+}\right)$ was calculated as the difference between baseline fluorescence and peak response to drug stimulation. For all experimental results, statistical comparisons were performed with oneway ANOVA with the Student-Newman-Keuls post hoc test using SigmaStat 3.5 (Systat Software). For all experiments, differences at the $p<$ 0.05 level were considered significant.

\section{Results}

\section{Surface biotinylation}

To determine whether $\mathrm{ER} \alpha$ is associated with the plasma membrane (Chaban et al., 2004) and regulated at the cell membrane by estradiol, astrocytes were surface biotinylated. With the C1355 $\mathrm{ER} \alpha$ antibody, which is directed toward the $\mathrm{COOH}$ terminal, two ER $\alpha$-immunoreactive bands were observed: a major band at 52 $\mathrm{kDa}$ seen after a 2 min exposure and a lower-intensity band at 66 $\mathrm{kDa}$ seen after a $2 \mathrm{~h}$ exposure to film (Fig. 1). Both bands were also observed with MC-20, ab3574, and H-184 antibodies directed against the $\mathrm{COOH}$ and $\mathrm{NH}_{2}$ terminals of $\mathrm{ER} \alpha$. Immunostaining for LIMK1, a cytoplasmic protein, was negative and verified the purity of the biotinylated sample. Antibodies directed against GPR30 were used to determine whether this putative membrane estradiol-binding protein was present in the membrane and could be surface biotinylated. However, no GPR30-immunoreactive bands were identified (Fig. $1 A$ ).

\section{ER $\alpha$ KO mouse experiment}

Surface biotinylation using astrocytes from $\mathrm{ER} \alpha \mathrm{KO}$ mice demonstrated an absence of both the 66 and $52 \mathrm{kDa} \mathrm{ER} \alpha$ bands in the plasma membrane. WT mice astrocytes revealed the same pattern of membrane ER $\alpha$ expression as rat astrocytes: a major $52 \mathrm{kDa}$ band and a minor $66 \mathrm{kDa}$ band. Both of these ER $\alpha$-immunoreactive bands were not detectable in the $\mathrm{ER} \alpha \mathrm{KO}$ astrocytes (supplemental material, available at www.jneurosci.org).

\section{Estradiol regulation of $\mathrm{ER} \alpha$ trafficking}

Estradiol transiently increased the amount $\operatorname{ER} \alpha$ in the plasma membrane. Both the 66 and $52 \mathrm{kDa} \mathrm{ER} \alpha$ bands responded in parallel to estradiol treatment and thus the $52 \mathrm{kDa} E R \alpha$ band was quantified (Figs. $1 B, C, 2 A$ ). Initially, the levels of membrane $\mathrm{ER} \alpha$ were low $(19 \pm 4 \% ; n=4)$, but estradiol treatment for $5 \mathrm{~min}$ significantly increased $\mathrm{ER} \alpha$ levels to $38 \pm 6 \%(n=4 ; p<0.05)$. Maximal membrane levels were seen at $30 \min (54 \pm 3 \% ; n=4$; $p<0.05)$ of estradiol treatment and remained elevated for $1 \mathrm{~h}$ $(42 \pm 6 \% ; n=4 ; p<0.05)$ before declining by $2 \mathrm{~h}(32 \pm 3 \% ; n=$ $4 ; p<0.05)$. The levels of ER $\alpha$ were minimal at $24-48 \mathrm{~h}$ of estradiol treatment despite the continuous presence of estradiol $(10 \pm 3$ and $9 \pm 3 \% ; n=4 ; p>0.05)$. Interestingly, the membrane estrogen receptor GPR30 was not detected by surface biotinylation and/or estradiol treatment (Fig. $2 \mathrm{~A}$ ).

Internalization is part of the mechanism of receptor desensitization and follows the binding of a natural ligand to its receptor. To test whether estradiol treatment would induce receptor internalization, cells were biotinylated and treated with estradiol for
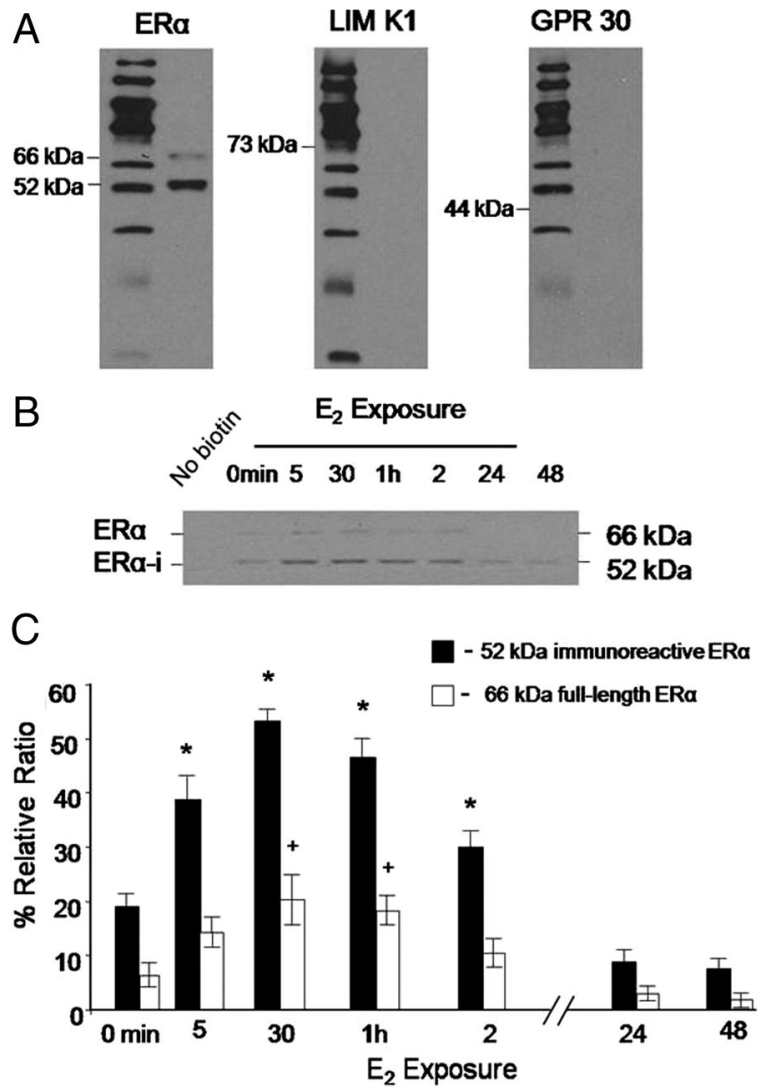

Figure 1. Postpubertal hypothalamic astrocytes were incubated with vehicle $(0 \mathrm{~min})$ or in the presence of $1 \mathrm{~nm}$ estradiol for 5 and $30 \mathrm{~min}$ and 1, 2, 24, and $48 \mathrm{~h}$. Astrocytes were then biotinylated, the biotin was removed, and the labeled proteins were separated and detected with $\mathrm{ER} \alpha$, GPR30, and LIM K1 antibodies. $\boldsymbol{A}$, Two ER $\alpha$-immunoreactive (ER $\alpha$-i) bands were identified: 66 and $52 \mathrm{kDa}$. The cytoplasmic protein LIM K1 and the putative membrane estrogen receptor GPR30 were not labeled with surface biotinylation. $\boldsymbol{B}$, Estradiol treatment increased both the 66 and $52 \mathrm{kDa}$ ER $\alpha$-i bands. In the first lane, cells were not surface biotinylated (no biotin), thus no biotinylated ER $\alpha$-i were labeled. Detection of the $66 \mathrm{kDA}$ ER $\alpha$ required a $2 \mathrm{~h}$ exposure compared with a 1-2 min exposure for the $52 \mathrm{kDa}$ ER $\alpha$-i. C, Quantification of the 66 and $52 \mathrm{kDa}$ ER $\alpha$-i bands was calculated by comparing optical density of the ER $\alpha$-i bands with the optical density of the $\beta$-actin bands. Both 66 and $52 \mathrm{kDa}$ ER $\alpha$-i bands are regulated in parallel by estradiol treatment, but the amount of $66 \mathrm{kDa} E R \alpha$ was much less at each time point. Data are mean \pm SEM $(n=4) .{ }^{*}{ }^{+}$Statistical differences at the $p<0.05$ level compared with 0 min for each molecular-weight species. $E_{2}$, Estradiol.

varying lengths of time, and then the biotin was stripped off the surface with glutathione. Therefore, only internalized ER would retain the biotin tag. Internalization paralleled the increase of $\mathrm{ER} \alpha$ in the membrane. The amount of internalized $\mathrm{ER} \alpha$ increased from $4 \pm 2 \%(n=4)$ at $0 \min$ to $20 \pm 3 \%$ at $5 \min (n=$ $4 ; p<0.05)$ and was maximal between $30 \mathrm{~min}$ and $1 \mathrm{~h}(47 \pm 4$ and $52 \pm 4 \%$, respectively; $n=4 ; p<0.05$ ). Although the amount of internalized $\mathrm{ER} \alpha$ was still significantly elevated at the $2 \mathrm{~h}$ time point ( $35 \pm 5 \% ; n=4 ; p<0.05)$, it was beginning to decrease compared with its peak concentration. By $24 \mathrm{~h}$, the levels of internalized receptor reached basal levels $(10 \pm 2 \% ; n=4 ; p>$ 0.05 ) (Fig. $2 B$ ) and remained low at the $48 \mathrm{~h}$ time point ( $12 \pm 3 \%$; $n=4 ; p>0.05)$.

To test whether ER $\alpha$ trafficking to the membrane depends on membrane or intracellular actions of estradiol, membraneimpermeable E-6-BSA was used. Cells were incubated with $1 \mathrm{nM}$ E-6-BSA for the experimental time course before biotinylation. Membrane-limited estradiol treatments did not change the levels of biotinylated $52 \mathrm{kDa} \operatorname{ER} \alpha(n=4 ; p>0.05)$ (Fig. $3 A)$. In fact, 
levels throughout the course of the experiment differed by $<5 \%$ and were not statistically different than the level measured at $0 \min (28 \pm 2 \% ; n=4)$ (Fig. $3 A)$. These results demonstrate that intracellular estradiol is required to induce trafficking of the $\mathrm{ER} \alpha$ to the membrane. Treatment with ICI 182,780 prevented ER $\alpha$ trafficking to the membrane and estradiolinduced internalization (Fig. $3 B, C$ ). As with E-6-BSA, ER $\alpha$ levels throughout the experiment did not change (Fig. $3 A-$ $C)$. Since GPR30 has been suggested to be associated with intracellular membranes, we tested the idea that estradiol was activating GPR30 to induce trafficking of ER $\alpha$ to the membrane. Astrocytes were incubated with the GPR30 agonist G-1. However, G-1 treatment failed to alter levels of biotinylated $52 \mathrm{kDa} \mathrm{ER} \alpha$ in the membrane. The amount of surfacebiotinylated $\mathrm{ER} \alpha$ varied from $16 \pm 2 \%(0$ $\min )$ to $21 \pm 3 \%$ at $1 \mathrm{~h}$ (data not shown). None of the levels of ER $\alpha$ were statistically different ( $n=4 ; p>0.05$ vs $0 \mathrm{~min}$ ).

\section{mGluR1a- and ER $\alpha$-immunoreactive trafficking}

Previously, we and others have reported that $\mathrm{ER} \alpha$ interacts with mGluRla on the plasma membrane to initiate cell signaling (Boulware et al., 2005; Dewing et al., 2007, 2008; Micevych and Mermelstein, 2008; Kuo et al., 2009). We tested whether mGluRla is also trafficked to the membrane by estradiol. After estradiol treatment, astrocytes were biotinylated, and mGluRla levels were detected by Western blotting. Estradiol increased the levels of mGluRla on the membrane (Fig. $4 \mathrm{~A}$ ), but the kinetics of mGluRla trafficking to the membrane showed a delayed pattern compared with the estradiol-induced increase in $\mathrm{ER} \alpha$. A statistically significant increase of mGluRla was first observed at the $30 \mathrm{~min}$ time point $(56 \pm 8 \% ; n=4 ; p<0.05$ vs 0 min) (Fig. $4 A$ ) compared with $\mathrm{ER} \alpha$, which was significantly increased at $5 \mathrm{~min}$ (Fig. $2 A$ ). Levels of mGluRla remained elevated at 1 and $2 \mathrm{~h}$ of estradiol treatment $(52 \pm 7$ and $48 \pm 5 \%$, respectively; $n=4 ; p<0.05)$ and slowly decreased by 24 and $48 \mathrm{~h} \mathrm{(36 \pm}$ 8 and $34 \pm 4 \%$, respectively; $n=4 ; p<0.05$ vs 0 min) (Fig. $4 A$ ) but still remained elevated compared with basal levels. Treating the astrocytes with the mGluRla antagonist LY 367385 prevented the estradiol-induced ER $\alpha$ trafficking to the membrane ( $n=4$; $p>0.05$ ) (Fig. $4 B$ ). Similarly, LY 367385 treatment blocked ER $\alpha$ internalization regardless of the duration of estradiol treatment $(n=4 ; p>0.05$ vs 0 min) (Fig. $4 C)$.

\section{Steroid-starvation effects the $\left[\mathrm{Ca}^{2+}\right]_{\mathrm{i}}$ response in astrocytes} Estradiol induces a rapid and robust $\left[\mathrm{Ca}^{2+}\right]_{\mathrm{i}}$ flux in hypothalamic astrocytes (Micevych et al., 2007; Kuo et al., 2009). Furthermore, the $\left[\mathrm{Ca}^{2+}\right]_{\mathrm{i}}$ response to estradiol at concentrations between 1 and $100 \mathrm{~nm}$ are similar (Kuo et al., 2009). Without prior steroid-starvation, estradiol at $10 \mathrm{nM}$ induced a moderate increase in $\left[\mathrm{Ca}^{2+}\right]_{\mathrm{i}}$ flux $\left(\Delta F \mathrm{Ca}^{2+}=339 \pm 18 \mathrm{RFU} ; n=27\right)$ (Fig. $5 A)$. Steroid-starvation increased the $\left[\mathrm{Ca}^{2+}\right]_{\mathrm{i}}$ response to estradiol stimulation. After steroid-starvation for 6 or $12 \mathrm{~h}$, estradiol at $10 \mathrm{nM}$ significantly increased the $\left[\mathrm{Ca}^{2+}\right]_{\mathrm{i}}$ response $\left(\Delta F \mathrm{Ca}^{2+}=\right.$
$503 \pm 19 \mathrm{RFU}, n=22, p<0.001$ vs no steroid-starvation; and $\Delta F$ $\mathrm{Ca}^{2+}=534 \pm 10 \mathrm{RFU}, n=26, p<0.001$ vs no steroidstarvation, respectively) (Fig. $5 A$ ). The prolonged absence of sex steroids increased the estradiol-induced $\left[\mathrm{Ca}^{2+}\right]_{\mathrm{i}}$ flux in hypothalamic astrocytes.

\section{Duration of estradiol exposure influences estradiol-induced $\left[\mathrm{Ca}^{2+}\right]_{\mathrm{i}}$ flux}

Incubation of hypothalamic astrocytes in $1 \mathrm{nM}$ estradiol influenced their subsequent response to estradiol stimulation at 10 nM. The $10 \mathrm{~nm}$ estradiol-induced $\left[\mathrm{Ca}^{2+}\right]_{\mathrm{i}}$ flux significantly increased after incubation with $1 \mathrm{nM}$ estradiol for $30 \mathrm{~min}\left(\Delta F \mathrm{Ca}^{2+}=\right.$ $594 \pm 17 \mathrm{RFU} ; n=29 ; p<0.05)$ compared with no previous exposure to estradiol ( $\Delta F \mathrm{Ca}^{2+}=534 \pm 10 \mathrm{RFU} ; n=26$ ) (Fig. $5 B$ ). The response to $10 \mathrm{~nm}$ estradiol stimulation did not increase significantly after previous exposure to estradiol at $1 \mathrm{nM}$ for $5 \mathrm{~min}$ $\left(\Delta F \mathrm{Ca}^{2+}=582 \pm 15 \mathrm{RFU} ; n=23 ; p>0.05\right), 1 \mathrm{~h}\left(\Delta F \mathrm{Ca}^{2+}=\right.$ $558 \pm 20 \mathrm{RFU} ; n=21 ; p>0.05)$, or $2 \mathrm{~h}\left(\Delta F \mathrm{Ca}^{2+}=547 \pm 11\right.$ RFU; $n=21 ; p>0.05)$ compared with no previous incubation with estradiol at $1 \mathrm{~nm}$ (Fig. 5B). All astrocytes were steroidstarved for a total of $12 \mathrm{~h}$ before stimulation with $10 \mathrm{~nm}$ estradiol. Previous exposure to estradiol increased the $\left[\mathrm{Ca}^{2+}\right]_{\mathrm{i}}$ response to subsequent estradiol stimulation with the maximum effect occurring after $30 \mathrm{~min}$ of estradiol exposure. The estradiol-induced $\left[\mathrm{Ca}^{2+}\right]_{\mathrm{i}}$ flux then decreased with increasing duration of estradiol incubation beyond $30 \mathrm{~min}$.

\section{Discussion}

Membrane $\operatorname{ER} \alpha$ has been associated with rapid estradiol-induced $\left[\mathrm{Ca}^{2+}\right]_{\mathrm{i}}$ flux, regulation of progesterone synthesis, and interaction with the mGluRla in neurons and astrocytes (Dewing et al., 2007; Micevych et al., 2007, 2009; Kuo et al., 2009). The major 

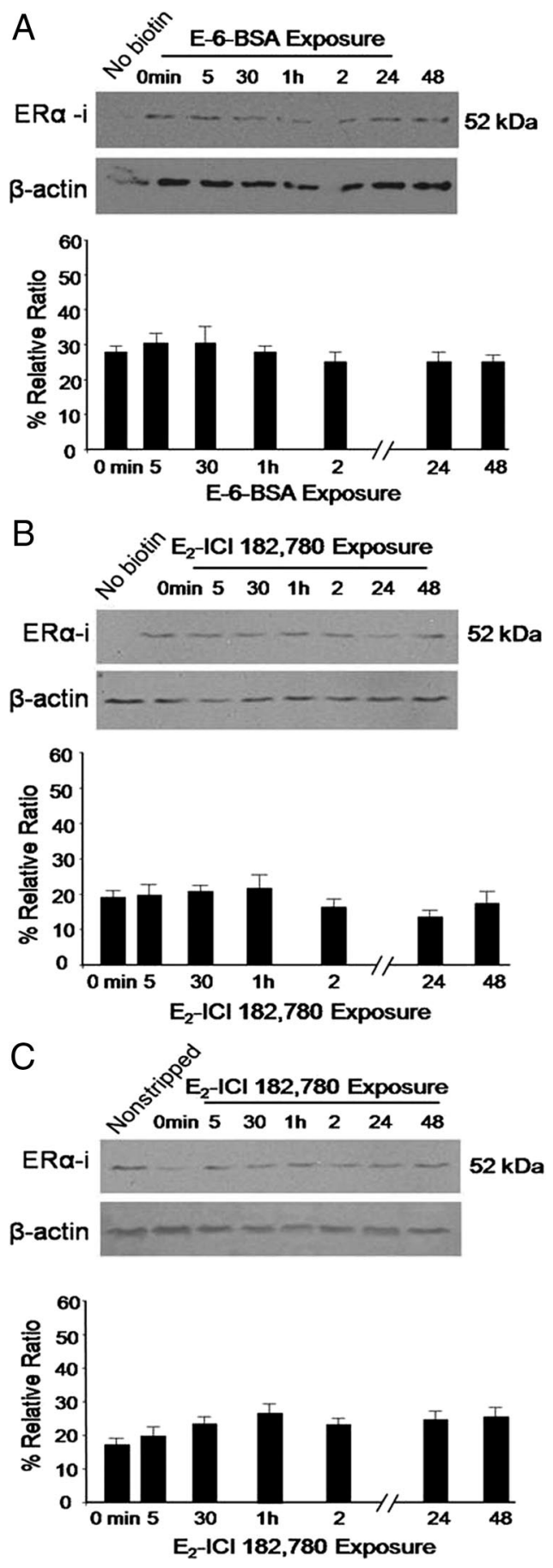

Figure 3. A, Postpubertal hypothalamic astrocytes were incubated with $1 \mathrm{~nm}$ E-6-BSA before biotinylation. The membrane-constrained estradiol did not change membrane levels of $E R \alpha$-immunoreactive ( $E R \alpha$-i) bands, indicating that estradiol acts within the cell to regulate $E R \alpha$-i band trafficking to the membrane. $\boldsymbol{B}$, To study the effect of estradiol on $E R \alpha$-i band trafficking to the membrane, cells were preincubated with charcoal-stripped medium containing $1 \mu \mathrm{M} \mathrm{ICl} \mathrm{182,780,} \mathrm{an} \mathrm{ER} \mathrm{antagonist,} \mathrm{for} 1 \mathrm{~h}$ before and during $1 \mathrm{~nm}$ estradiol treatment. ICI 182,780 prevented trafficking of ER $\alpha$-i bands to the membrane. $C$, To study the effect of estradiol on $E R \alpha$-i band internalization, cells were surface biotinylated and treated with estradiol ( $1 \mathrm{nM})$ and ICI 182,780 (1 $\mu \mathrm{M})$, which prevented internalization of ER $\alpha$-i band. All the data are mean $\pm \operatorname{SEM}(n=4)$. * Differences at the $p<0.05$ level compared with 0 min for each experiment. $E_{2}$, Estradiol.
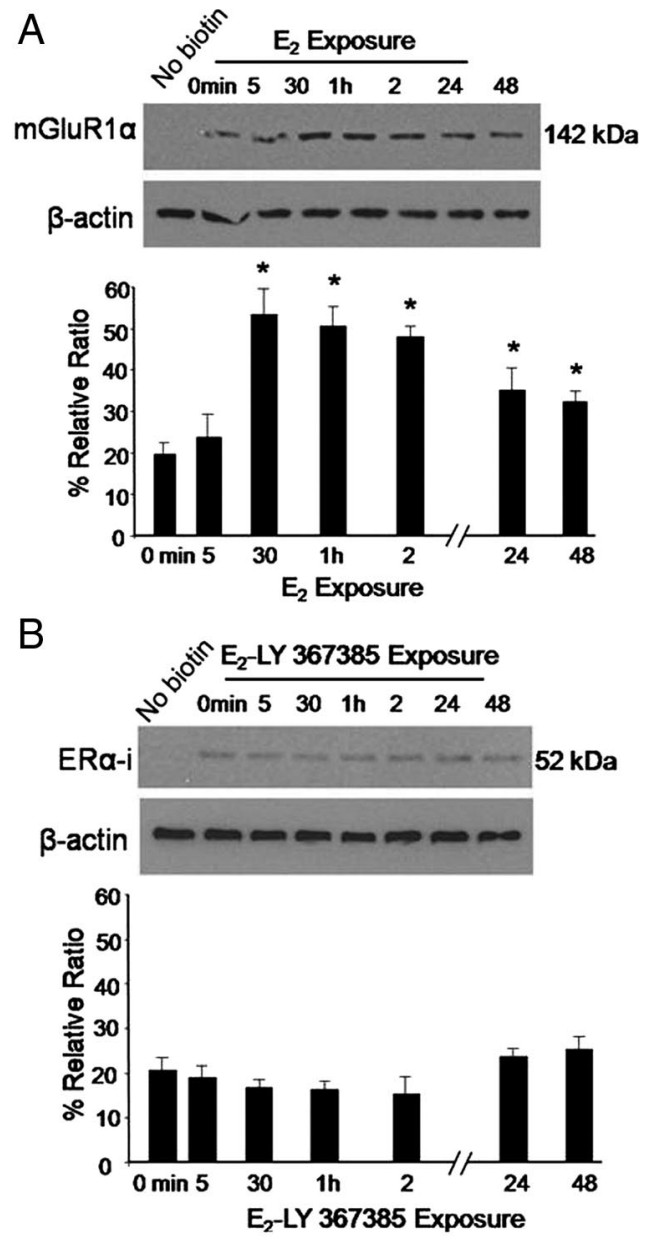

C


Figure 4. A, To detect whether estradiol regulates mGluR1a trafficking, postpubertal hypothalamic astrocytes were treated with estradiol $(1 \mathrm{nM})$ for the indicated times and surface biotinylated. Levels of membrane mGluR1a were increased by estradiol treatment. By 30 min, mGluR1a levels were significantly higher than no previous estradiol treatment $\left(0 \mathrm{~min} ;{ }^{*} p<0.05\right)$. Membrane levels of mGluR1a did not return to basal levels during the experiment ( $48 \mathrm{~h}$ ). $\boldsymbol{B}$, The mGluR1a antagonist LY $367385(50 \mu \mathrm{M})$ blocked the estradiol-induced $E R \alpha$-immunoreactive (ER $\alpha$-i) trafficking to the membrane. C, Similarly, $50 \mu \mathrm{M}$ LY 367385 prevented the estradiol-induced ER $\alpha$-i internalization. All the data are mean \pm SEM $(n=4)$. ${ }^{*}$ Differences at the $p<0.05$ level compared with 0 min for each experiment. $E_{2}$, Estradiol. 
A
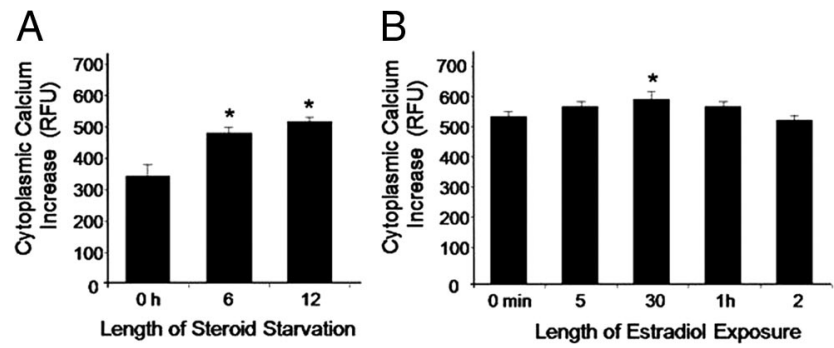

Figure 5. $\boldsymbol{A}$, Duration of steroid-starvation increased the estradiol-induced $\left[\mathrm{Ca}^{2+}\right]_{\mathrm{i}}$ flux in postpubertal hypothalamic astrocytes. Estradiol at $10 \mathrm{~nm}$ induced a greater $\left[\mathrm{Ca}^{2+}\right]_{\mathrm{i}}$ response after a $6 \mathrm{~h}\left({ }^{*} p<0.001\right)$ and $12 \mathrm{~h}\left({ }^{*} p<0.001\right)$ steroid-starvation compared with no prior $(0 \mathrm{~h})$ steroid-starvation. $\boldsymbol{B}$, Prior estradiol exposure transiently increased $\left[\mathrm{Ca}^{2+}\right]_{i}$ flux in astrocytes. After a $12 \mathrm{~h}$ steroid-starvation without previous estradiol incubation ( $0 \mathrm{~min}$ ), estradiol at $10 \mathrm{~nm}$ induced a robust $\left[\mathrm{Ca}^{2+}\right]_{\mathrm{i}}$ flux. The $10 \mathrm{~nm}$ estradiol-induced $\left[\mathrm{Ca}^{2+}\right]_{\mathrm{i}}$ flux increased after exposure to $1 \mathrm{~nm}$ estradiol for $30 \mathrm{~min}\left({ }^{*} p<0.05\right)$. However, incubation with $1 \mathrm{~nm}$ estradiol for $5 \mathrm{~min}$, $1 \mathrm{~h}$, or $2 \mathrm{~h}$ ( $p>0.05$ ) was no different than no prior incubation with estradiol ( $0 \mathrm{~min})$. All the data are mean \pm SEM. ${ }^{*}$ Differences at the $p<0.05$ level compared with 0 min.

finding of this study is that estradiol regulates $\mathrm{ER} \alpha$ trafficking into and out of the plasma membrane. Surface biotinylation revealed two $\mathrm{ER} \alpha$-immunoreactive bands: a full-length $66 \mathrm{kDa}$ and a smaller $52 \mathrm{kDa} \mathrm{ER} \alpha$, both of which are regulated in parallel by estradiol. Trafficking to the membrane was not induced by E-6BSA and was blocked by the ER antagonist ICI 182,780 and the mGluR1a antagonist LY 367385. Similarly, internalization, a measure of receptor activation, was blocked by ICI 182,780 and LY 367385. As a measure of ER $\alpha$ signaling, $\left[\mathrm{Ca}^{2+}\right]_{\mathrm{i}}$ flux was also shown to be maximal when the amount of biotinylated ER $\alpha$ in membrane was highest. These results are consistent with the hypothesis that $\mathrm{ER} \alpha$ is a membrane receptor with an extracellular portion whose levels are regulated by estradiol, temporally limiting membrane-initiated cell signaling.

A number of different techniques have been used to demonstrate membrane association of ERs. A particularly useful method has been to use membrane-constrained estradiol constructs such as E-6-BSA or estradiol conjugated to biotin (E-biotin). The membrane-impermeable conjugates of estradiol has been shown to elicit rapid activation of cell signaling pathways (Beyer et al., 2003; Chaban et al., 2004; Kelly and Ronnekleiv, 2008; Mermelstein and Micevych, 2008). Western blotting revealed ER $\alpha$ and ER $\beta$ in membrane fractions of neurons and astrocytes (Azcoitia et al., 1999; Chaban et al., 2004; Pawlak et al., 2005). Furthermore, coimmunoprecipitation experiments showed an interaction of $66 \mathrm{kDa} \mathrm{ER} \alpha$ with mGluRla in membrane fractions of astrocytes and neurons (Dewing et al., 2007; Kuo et al., 2009). This interaction is necessary for estradiol cell signaling (Boulware et al., 2005; Dewing et al., 2007, 2008; Kuo et al., 2009). Surface biotinylation with the Sulfo-NHS-SS-Biotin reagent is a convenient method for the identification of cell-surface proteins and can be used to study membrane protein trafficking. An advantage is that Sulfo-NHS-Biotin is membrane impermeable and labels only proteins that have extracellular lysine residues. This was verified by showing that LIMK1, a cytoplasmic protein, was not labeled (Fig. 1), whereas mGluRla, a typical seven-membrane pass G-protein-coupled receptor, was labeled (Fig. 4). Treatment with estradiol not only increased trafficking of ER $\alpha$ to the membrane, but also its internalization (Fig. 2). The current observations of receptor internalization complement studies using a membrane-impermeable E-6-BSA-FITC construct, which binds to and labels membrane ERs (Dominguez et al., 2009; Micevych and Dominguez, 2009). GPR30, a putative G-protein-coupled
ER, was not detected in surface-biotinylated fractions from astrocytes (Figs. 1,2), confirming previous results that suggest that GPR30 may not be present on the cell membrane (Gorosito et al., 2008; Matsuda et al., 2008; Otto et al., 2008).

Hydropathicity analysis of $\mathrm{ER} \alpha$ suggests a potential transmembrane domain near the $\mathrm{NH}_{2}$ terminal (SOSUI, TMpred program). This supports potential extracellular ER $\alpha$ binding sites. Our current biotinylation experiments did not indicate which part of the ER $\alpha$ extends through the membrane but did suggest that there is an extracellular portion whose characterization will require additional study. Interestingly, the present surfacebiotinylation studies identified two $\mathrm{ER} \alpha$ forms: a $66 \mathrm{kDa}$ and a 52 $\mathrm{kDa} \mathrm{ER} \alpha$ band. A similar, 50/55 kDa ER $\alpha$-immunoreactive band was surface biotinylated in embryonic hypothalamic neurons, but no $66 \mathrm{kDa}$ bands were detected (Gorosito et al., 2008). In oligodendrocytes, the MC-20 (anti-ER $\alpha$ antibody) labeled a 66 $\mathrm{kDa}$ band and an $\sim 52 \mathrm{kDa}$ doublet (Gorosito et al., 2008). Interestingly, both full-length $66 \mathrm{kDa} \mathrm{ER} \alpha$ and $55 \mathrm{kDa} \mathrm{ER} \alpha$ were identified in an endothelial cell line derived from the hypothalamus (Deecher et al., 2003). However, only the full-length ER $\alpha$ could bind estradiol and increase $\left[\mathrm{Ca}^{2+}\right]_{\mathrm{i}}$ flux, suggesting that the $55 \mathrm{kDa}$ band may have been a proteolytic/degradation fragment. In the present study, the $52 \mathrm{kDa}$ may also be a proteolytic/degradation product, but without further characterization, this would be a premature conclusion. Every precaution was taken to prevent degradation during our experiments. All procedures were done at $4^{\circ} \mathrm{C}$ and in the presence of several protease inhibitors. Moreover, the $52 \mathrm{kDa}$ band was labeled with $\mathrm{COOH}-$ and $\mathrm{NH}_{2}$ teminally directed antibodies.

Previous studies have discovered various splice variants of $\mathrm{ER} \alpha$ in different tissues, including the CNS (Couse et al., 1995; Bollig and Miksicek, 2000; Kos et al., 2002; Shughrue et al., 2002; Herynk and Fuqua, 2004; Nethrapalli et al., 2005; Perlman et al., 2005; Dominguez-Salazar et al., 2006). Using an ER $\alpha$ KO mouse model, we confirmed that both $\mathrm{ER} \alpha$-immunoreactive proteins identified in our WT mice and rat experiments are derived from the ER $\alpha$ gene (supplemental material, available at www.jneurosci. org). It is likely that the $52 \mathrm{kDa}$ protein is a splice variant. mRNAs missing exon $7(\operatorname{ER} \alpha \Delta 7)$ are predicted to code for a protein of $\sim 52 \mathrm{kDa}$, but this protein is missing the $\mathrm{COOH}$ terminal. However, we were able to identify the $52 \mathrm{kDa}$ protein with antibodies directed against both the $\mathrm{NH}_{2}$ and $\mathrm{COOH}$ termini, suggesting that this protein is not derived from $\operatorname{ER} \alpha \Delta 7$, but rather another slice variant. A potential splice variant is $\operatorname{ER} \alpha \Delta 4$, which codes for an $\sim 54 \mathrm{kDa}$ protein that has both the $\mathrm{NH}_{2}$ and $\mathrm{COOH}$ termini conserved and could interact with our antibodies (Fuqua et al., 1992; Bollig and Miksicek, 2000; Deecher et al., 2003; Perlman et al., 2005). At the present time, the identity of this lower-weight, $52 \mathrm{kDa} \mathrm{ER} \alpha$-immunoreactive protein is not known and will require further characterization.

In previous studies, only the $66 \mathrm{kDa} \mathrm{ER} \alpha$ coimmunoprecipitated with mGluRla, which in astrocytes is needed for the estradiol-induced $\left[\mathrm{Ca}^{2+}\right]_{\text {i }}$ flux (Chaban et al., 2004; Kuo et al., 2009). In the present study, the estradiol-induced increase of $\left[\mathrm{Ca}^{2+}\right]_{\mathrm{i}}$ flux paralleled the levels of the $66 \mathrm{kDa}$ form and did not coincide with the large changes in the $52 \mathrm{kDa}$ level.

Regardless, the $52 \mathrm{kDa} \mathrm{ER} \alpha$ is a useful marker for membrane $\mathrm{ER} \alpha$ because it is regulated in parallel to $66 \mathrm{kDa} \mathrm{ER} \alpha$, and the 52 $\mathrm{kDa} \mathrm{ER} \alpha$ is easier to detect. Therefore, the $52 \mathrm{kDa}$ form was quantified for the trafficking and internalization studies. Estradiol treatment had a biphasic effect on levels of surfacebiotinylated $\mathrm{ER} \alpha$. Within $5 \mathrm{~min}$, estradiol acting within the cell, in an ICI 182,780-dependent manner, dramatically increased 
membrane $\mathrm{ER} \alpha$ trafficking and internalization. Interestingly, treatment with the mGluR1a antagonist LY 367385 also prevented $\mathrm{ER} \alpha$ trafficking to the membrane and internalization, consistent with the idea of a direct $\mathrm{ER} \alpha$-mGluRla interaction.

The response of $\mathrm{ER} \alpha$ to estradiol stimulation is interesting because it suggests an auto-regulation of MISS. These results indicate that there is a $2 \mathrm{~h}$ window during which estradiol induces membrane trafficking and internalization of $\mathrm{ER} \alpha$. The rapidity of the trafficking to the membrane suggests that de novo synthesis of $\mathrm{ER} \alpha$ is probably not occurring. Estradiol is inducing exocytosis of vesicles that have $\mathrm{ER} \alpha$ inserted in the membrane as has been reported on neuronal vesicles in hippocampal neurons (Milner et al., 2001; Hart et al., 2007) and in pituitary cells (Gonzalez et al., 2008). ERs are targeted to membranes through palmitoylation and in association with caveolin proteins that also regulate the interaction with mGluRs (Acconcia et al., 2005; Boulware et al., 2007; Pedram et al., 2007; Micevych and Mermelstein, 2008). When $\mathrm{ER} \alpha$ vesicles fuse with the cell membrane, they deliver the ER $\alpha$-mGluR complex to the cell surface. Similarly, internalization also has been linked to the formation of endocytic vesicles in which E-6-BSA-FITC is sequestered (Micevych and Dominguez, 2009). Once receptors are internalized and release their ligand, they can either be recycled to the cell surface or degraded. Our results suggest that for several hours $\mathrm{ER} \alpha$ was recycled since sequestration of the receptor paralleled the highest levels of ER $\alpha$ in the membrane (Fig. 2). Continuous treatment with estradiol for 24-48 h leads to a decreased concentration in plasma membrane and internalized levels of $\mathrm{ER} \alpha$, suggesting that estradiol exposure eventually leads to degradation of the receptor and downregulation. This indicates that rapid estradiol signaling is temporally restricted. In vivo, only membrane-constrained E-6-BSA given before estradiol was facilitatory (Kow and Pfaff, 2004).

Understanding the regulation of ER $\alpha$ levels in the plasma membrane is fundamental for the understanding of estradiol signaling. Levels of membrane $\mathrm{ER} \alpha$ result from the balance between exocytosis and endocytosis, which we demonstrate as being regulated by estradiol acting in astrocytes. Thus, the present study indicates a novel autoregulation of $\mathrm{ER} \alpha$ and MISS by estradiol.

\section{References}

Acconcia F, Ascenzi P, Bocedi A, Spisni E, Tomasi V, Trentalance A, Visca P, Marino M (2005) Palmitoylation-dependent estrogen receptor alpha membrane localization: regulation by 17beta-estradiol. Mol Biol Cell 16:231-237.

Azcoitia I, Sierra A, Garcia-Segura LM (1999) Localization of estrogen receptor beta-immunoreactivity in astrocytes of the adult rat brain. Glia 26:260-267.

Beyer C, Pawlak J, Karolczak M (2003) Membrane receptors for oestrogen in the brain. J Neurochem 87:545-550.

Bollig A, Miksicek RJ (2000) An estrogen receptor-alpha splicing variant mediates both positive and negative effects on gene transcription. Mol Endocrinol 14:634-649.

Boulware MI, Weick JP, Becklund BR, Kuo SP, Groth RD, Mermelstein PG (2005) Estradiol activates group I and II metabotropic glutamate receptor signaling, leading to opposing influences on cAMP response elementbinding protein. J Neurosci 25:5066-5078.

Boulware MI, Kordasiewicz H, Mermelstein PG (2007) Caveolin proteins are essential for distinct effects of membrane estrogen receptors in neurons. J Neurosci 27:9941-9950.

Brandli AW, Parton RG, Simons K (1990) Transcytosis in MDCK cells: identification of glycoproteins transported bidirectionally between both plasma membrane domains. J Cell Biol 111:2909-2921.

Busch G, Hoder D, Reutter W, Tauber R (1989) Selective isolation of individual cell surface proteins from tissue culture cells by a cleavable biotin label. Eur J Cell Biol 50:257-262.

Chaban VV, Mayer EA, Ennes HS, Micevych PE (2003) Estradiol inhibits
ATP-induced intracellular calcium concentration increase in dorsal root ganglia neurons. Neuroscience 118:941-948.

Chaban VV, Lakhter AJ, Micevych P (2004) A membrane estrogen receptor mediates intracellular calcium release in astrocytes. Endocrinology 145:3788-3795.

Couse JF, Curtis SW, Washburn TF, Lindzey J, Golding TS, Lubahn DB, Smithies O, Korach KS (1995) Analysis of transcription and estrogen insensitivity in the female mouse after targeted disruption of the estrogen receptor gene. Mol Endocrinol 9:1441-1454.

Deecher DC, Swiggard P, Frail DE, O'Connor LT (2003) Characterization of a membrane-associated estrogen receptor in a rat hypothalamic cell line (D12). Endocrine 22:211-223.

Dewing P, Boulware MI, Sinchak K, Christensen A, Mermelstein PG, Micevych P (2007) Membrane estrogen receptor-alpha interactions with metabotropic glutamate receptor la modulate female sexual receptivity in rats. J Neurosci 27:9294-9300.

Dewing P, Christensen A, Bondar G, Micevych P (2008) Protein kinase C signaling in the hypothalamic arcuate nucleus regulates sexual receptivity in female rats. Endocrinology 149:5934-5942.

Dominguez R, Hu E, Zhou M, Baudry M (2009) 17Beta-estradiol-mediated neuroprotection and ERK activation require a pertussis toxin-sensitive mechanism involving GRK2 and $\beta$-arrestin-1. J Neurosci 29:4228-4238.

Dominguez-Salazar E, Shetty S, Rissman EF (2006) Rapid neural Fos responses to oestradiol in oestrogen receptor alphabeta double knockout mice. J Neuroendocrinol 18:195-202.

Eckersell CB, Popper P, Micevych PE (1998) Estrogen-induced alteration of mu-opioid receptor immunoreactivity in the medial preoptic nucleus and medial amygdala. J Neurosci 18:3967-3976.

Fuqua SA, Fitzgerald SD, Allred DC, Elledge RM, Nawaz Z, McDonnell DP, O’Malley BW, Greene GL, McGuire WL (1992) Inhibition of estrogen receptor action by a naturally occurring variant in human breast tumors. Cancer Res 52:483-486.

Gonzalez M, Reyes R, Damas C, Alonso R, Bello AR (2008) Oestrogen receptor alpha and beta in female rat pituitary cells: an immunochemical study. Gen Comp Endocrinol 155:857-868.

Gorosito SV, Lorenzo AG, Cambiasso MJ (2008) Estrogen receptor alpha is expressed on the cell-surface of embryonic hypothalamic neurons. Neuroscience 154:1173-1177.

Hammes SR, Levin ER (2007) Extranuclear steroid receptors: nature and actions. Endocr Rev 28:726-741.

Hart SA, Snyder MA, Smejkalova T, Woolley CS (2007) Estrogen mobilizes a subset of estrogen receptor-alpha-immunoreactive vesicles in inhibitory presynaptic boutons in hippocampal CA1. J Neurosci 27:2102-2111.

Herynk MH, Fuqua SA (2004) Estrogen receptor mutations in human disease. Endocr Rev 25:869-898.

Hirahara Y, Matsuda K, Gao W, Arvanitis DN, Kawata M, Boggs JM (2009) The localization and non-genomic function of the membrane-associated estrogen receptor in oligodendrocytes. Glia 57:153-165.

Ivanova T, Karolczak M, Beyer C (2001) Estrogen stimulates the mitogenactivated protein kinase pathway in midbrain astroglia. Brain Res 889:264-269

Kelly MJ, Levin ER (2001) Rapid actions of plasma membrane estrogen receptors. Trends Endocrinol Metab 12:152-156.

Kelly MJ, Ronnekleiv OK (2008) Membrane-initiated estrogen signaling in hypothalamic neurons. Mol Cell Endocrinol 290:14-23.

Kos M, Denger S, Reid G, Korach KS, Gannon F (2002) Down but not out? A novel protein isoform of the estrogen receptor alpha is expressed in the estrogen receptor alpha knockout mouse. J Mol Endocrinol 29:281-286.

Kow LM, Pfaff DW (2004) The membrane actions of estrogens can potentiate their lordosis behavior-facilitating genomic actions. Proc Natl Acad Sci U S A 101:12354-12357.

Kuo J, Hariri OR, Bondar G, Ogi J, Micevych P (2009) Membrane estrogen receptor-alpha interacts with metabotropic glutamate receptor type la to mobilize intracellular calcium in hypothalamic astrocytes. Endocrinology 150:1369-1376.

Lagrange AH, Ronnekleiv OK, Kelly MJ (1995) Estradiol-17 beta and muopioid peptides rapidly hyperpolarize GnRH neurons: a cellular mechanism of negative feedback? Endocrinology 136:2341-2344.

Lagrange AH, Wagner EJ, Ronnekleiv OK, Kelly MJ (1996) Estrogen rapidly attenuates a GABAB response in hypothalamic neurons. Neuroendocrinology 64:114-123.

Li J, Micevych P, McDonald J, Rapkin A, Chaban V (2008) Inflammation in 
the uterus induces phosphorylated extracellular signal-regulated kinase and substance $\mathrm{P}$ immunoreactivity in dorsal root ganglia neurons innervating both uterus and colon in rats. J Neurosci Res 86:2746-2752.

Lin JW, Ju W, Foster K, Lee SH, Ahmadian G, Wyszynski M, Wang YT, Sheng M (2000) Distinct molecular mechanisms and divergent endocytotic pathways of AMPA receptor internalization. Nat Neurosci 3:1282-1290.

Matsuda K, Sakamoto H, Mori H, Hosokawa K, Kawamura A, Itose M, Nishi M, Prossnitz ER, Kawata M (2008) Expression and intracellular distribution of the $\mathrm{G}$ protein-coupled receptor 30 in rat hippocampal formation. Neurosci Lett 441:94-99.

Mermelstein PG, Micevych PE (2008) Nervous system physiology regulated by membrane estrogen receptors. Rev Neurosci 19:413-424.

Mhyre AJ, Dorsa DM (2006) Estrogen activates rapid signaling in the brain: role of estrogen receptor alpha and estrogen receptor beta in neurons and glia. Neuroscience 138:851-858.

Micevych PE, Dominguez R (2009) Membrane estradiol signaling in the brain. Front Neuroendocrinol 30:315-327.

Micevych PE, Mermelstein PG (2008) Membrane estrogen receptors acting through metabotropic glutamate receptors: an emerging mechanism of estrogen action in brain. Mol Neurobiol 38:66-77.

Micevych PE, Chaban V, Ogi J, Dewing P, Lu JK, Sinchak K (2007) Estradiol stimulates progesterone synthesis in hypothalamic astrocyte cultures. Endocrinology 148:782-789.

Micevych P, Kuo J, Christensen A (2009) Physiology of membrane estrogen receptor signaling in reproduction. J Neuroendocrinol 21:249-256.

Milner TA, McEwen BS, Hayashi S, Li CJ, Reagan LP, Alves SE (2001) Ultrastructural evidence that hippocampal alpha estrogen receptors are located at extranuclear sites. J Comp Neurol 429:355-371.

Nethrapalli IS, Tinnikov AA, Krishnan V, Lei CD, Toran-Allerand CD (2005) Estrogen activates mitogen-activated protein kinase in native, nontransfected CHO-K1, COS-7, and RAT2 fibroblast cell lines. Endocrinology 146:56-63.

Otto C, Rohde-Schulz B, Schwarz G, Fuchs I, Klewer M, Brittain D, Langer G, Bader B, Prelle K, Nubbemeyer R, Fritzemeier KH (2008) G proteincoupled receptor 30 localizes to the endoplasmic reticulum and is not activated by estradiol. Endocrinology 149:4846-4856.
Pawlak J, Karolczak M, Krust A, Chambon P, Beyer C (2005) Estrogen receptor-alpha is associated with the plasma membrane of astrocytes and coupled to the MAP/Src-kinase pathway. Glia 50:270-275.

Pedram A, Razandi M, Levin ER (2006) Nature of functional estrogen receptors at the plasma membrane. Mol Endocrinol 20:1996-2009.

Pedram A, Razandi M, Sainson RC, Kim JK, Hughes CC, Levin ER (2007) A conserved mechanism for steroid receptor translocation to the plasma membrane. J Biol Chem 282:22278-22288.

Perlman WR, Matsumoto M, Beltaifa S, Hyde TM, Saunders RC, Webster MJ, Rubinow DR, Kleinman JE, Weickert CS (2005) Expression of estrogen receptor alpha exon-deleted mRNA variants in the human and nonhuman primate frontal cortex. Neuroscience 134:81-95.

Sabarth N, Lamer S, Zimny-Arndt U, Jungblut PR, Meyer TF, Bumann D (2002) Identification of surface proteins of Helicobacter pylori by selective biotinylation, affinity purification, and two-dimensional gel electrophoresis. J Biol Chem 277:27896-27902.

Sakuma S, Tokuhara D, Hattori H, Matsuoka O, Yamano T (2009) Expression of estrogen receptor alpha and beta in reactive astrocytes at the male rat hippocampus after status epilepticus. Neuropathology 29:55-62.

Shughrue PJ, Askew GR, Dellovade TL, Merchenthaler I (2002) Estrogenbinding sites and their functional capacity in estrogen receptor double knockout mouse brain. Endocrinology 143:1643-1650.

Sinchak K, Mills RH, Tao L, LaPolt P, Lu JK, Micevych P (2003) Estrogen induces de novo progesterone synthesis in astrocytes. Dev Neurosci 25:343-348.

Wade CB, Robinson S, Shapiro RA, Dorsa DM (2001) Estrogen receptor (ER)alpha and ERbeta exhibit unique pharmacologic properties when coupled to activation of the mitogen-activated protein kinase pathway. Endocrinology 142:2336-2342.

Watters JJ, Dorsa DM (1998) Transcriptional effects of estrogen on neuronal neurotensin gene expression involve cAMP/protein kinase A-dependent signaling mechanisms. J Neurosci 18:6672-6680.

Zhao L, Brinton RD (2007) Estrogen receptor alpha and beta differentially regulate intracellular $\mathrm{Ca}(2+)$ dynamics leading to ERK phosphorylation and estrogen neuroprotection in hippocampal neurons. Brain Res 1172: $48-59$. 